\title{
Working from Home/In Quarantine: Commodifying COVID-19 "lockdown" period in India.
}

Nagendra Kumar ${ }^{1}$ and Prashant Maurya ${ }^{2}$

Indian Institute of Technology Roorkee, India

\begin{abstract}
In this paper, we are examining the sponsored advertisement posts/regular post on Facebook of a few business enterprises based in India to promote their products during first two phases of COVID-19 lockdown period. As a marketing and product promotion strategy, many business companies use social media platforms like Facebook and others to advertise their product through quick sponsored posts from time to time. As the use of social media has increased during the lockdown period when people are spending their whole time at home for a more extended period, these sponsored posts are more likely to be hit by the viewers. The present paper studies the contents of select sponsored posts/regular posts on Facebook to show how the "lockdown" period created atmospherics for E-commerce businesses. It also argues that by using topical words and phrases like "quarantine" and "work from home" respectively, as a tempting marketing strategy, the capitalist enterprises are using this time of distress, global misery and tribulation, for promoting their business.
\end{abstract}

Keywords: COVID-19, Facebook, sponsored advertisements, marketing strategy, Ecommerce.

\section{Introduction}

The COVID-19 pandemic has resulted in a sudden increase in online social media (Newman, 2020). The onslaught of the COVID-19 pandemic has driven people towards the use of social media, especially Facebook, which has experienced record usage during the ongoing epidemic (Swartz, 2020). Facebook functions not only a site for virtual human interaction but has been a potential site for providing news/information during the pandemic. Hutchinson

\footnotetext{
${ }^{1}$ Email: nagendra.kumar@hs.iitr.ac.in

22Email: pmaurya@hs.iitr.ac.in
} 
(2020) and Kadam \& Atre (2020) reiterate that, along with spreading awareness, social media like Facebook has been used to proliferate fake news (italics ours). Also, in recent years, Facebook has firmly established itself in advertising and marketing businesses. In 2019, the company earned $98.5 \%$ (close to 69.7 billion U. S. dollars) of its revenue from the advertisements and stood at top among the other social media platforms in terms of revenue generation (Clement, 2020).

Writing about the modern consumer society, Jean Baudrillard (1970) observes that "the human of the age of affluence are surrounded not so much by other human beings, as they were in all previous ages, but by objects" (p. 25). These objects in the form of goods and messages, present on online marketing sites and advertised by social media snare the acquisitive consumers. The trend of online shopping in India has increased tremendously in the last few years. One of the reasons is the remarkable revolution in the field of the internet. As a result, the internet is now quickly and cheaply available to the Indians. According to a report by Internet and Mobile Association of India, "with 451 million monthly active internet users at the end of the financial year of 2019, India is now second only to China in terms of internet users" (Mandavia, 2019). In addition to this, numerous benefits, such as, 24/7 services, fluctuating prices of products, discounts, offers and cashback, free home deliveries, thousands of products catalogued at one platform, customer reviews, private shopping, easy accessibility of E-commerce firms on mobile applications, products on credits, or pay later options, etc. are the factors that have motivated the tech-savvy consumers to prefer online shopping over outdoor shopping. Also, there is limitless freedom for the customers to surf and spend time, according to your convenience, 24/7 on E-commerce websites, which is not possible with outdoor shopping.

Both offline and online modes of shopping have their pros and cons; nevertheless, the online way is becoming more popular day by day. According to Indian Retail Industry Report 
(2019), "India is expected to become the world's fastest-growing e-commerce market, driven by robust investment in the sector and rapid increase in the number of internet users". Besides, in monetary value, according to IBEF, "the Indian online retail market is likely to touch US\$100 billion by 2020” (qtd in Prashar et al., 2017). Schwarzl and Grabowska (2015) note that "online marketing offers an enormous amount of possibilities for the companies" ( $\mathrm{p}$. 195). Even the small and medium-sized enterprises (SMEs) are taking the help of "digital platforms like Facebook to connect with customers and suppliers" (Schilirò 1711). Now with such a vast, ever-expanding pool of opportunities in Electronic Retailing in India, the firms have competition among them to create a commercial space to maximise the sale of their products. To do so, the companies are investing handsome amounts to their marketing and advertising units. Thus along with the traditional marketing system, where a product is advertised in newspapers and televisions, the companies now are using social media platforms to promote their products to reach a broader audience/consumer base. According to Deloitte,

The increasing popularity of digital media has provided for a paradigm shift in the global advertising spends. Marketers are following the changing trend and increasing allocating their budget to digital mediums. Spending on digital media as a percentage of total advertising spend is expected to reach $36 \%$ by 2020 . This increase is mainly coming by cannibalising traditional advertising mediums like print. (n. d.)

It further states that the "s-curve growth expectations for the overall digital ad market in India that include probable cannibalisation of ad revenues from other traditional segments like TV, radio, and print media indicate the digital ad market size of Rs 354 billion by 2020" (n. d.). 
India had called for a twenty-one day complete lockdown beginning from 24 March 2020 to stop spreading of coronavirus. As of 25 March 2020, 562 people were identified with COVID-19 (Osadchuk et al., 29). Later, after reviewing the situation, the lockdown was extended until 31 May 2020 in three more phases $^{3}$. From 1 June 2020, the government has started unlocking India under the complete monitor and with certain restrictions. No doubt, the lockdown has affected every stratum of Indian society and has hampered the economic growth of the country. Sharma \& Mahendru (2020) suggested it would leave a lasting impact on the Indian economy. The lockdown also has societal as well as psychological repercussions, as indicated by Herat (2020). During the first two phases of lockdown, the Indian government had put a hold on the production, supply and business of "non-essential goods'. However, delivery, manufacturing, and buy-sell of food, groceries and daily use items, under the subject 'essential goods' were allowed to continue. The E-Commerce companies were running their services for 'essential goods' with a low number of staffs. According to World Trade Organization (2020), "The enforcement of social distancing, lockdowns and other measures in response to the COVID-19 pandemic has led consumers to ramp up online shopping and social media use". It further reiterates that lockdown has resulted in a sharp rise in online purchasing, "as many consumers resorted to online shopping - either internet-enabled or by telephone".

In the light of the background as mentioned above, the present article analyses the contents of select sponsored posts/regular posts on Facebook during the first two phases of lockdown to show how the "lockdown period" created atmospherics for E-commerce businesses. It argues that by using topical words and phrases like "quarantine" and "work from home" respectively, as a tempting marketing strategy, the capitalist enterprises used the time of distress, global misery and tribulation, for promoting their business.

\footnotetext{
${ }^{3}$ Phase 1 (25 March 2020 -14 April 2020), Phase 2 (15 April 2020-3 May 2020), Phase 3 (4-17 May 2020), Phase 4 (18-31May 2020).
} 


\section{Materials and Method}

The present study is a qualitative study relying on observation and interpretation. Although there are $\mathrm{n}$ numbers of examples available, we have restricted ourselves only to select sponsored advertisement posts/regular post of a few business enterprises floated on Facebook. These advertisements are done by posting a picture of the product and a message on Facebook. Sometimes the company posts only a picture of the product. These business enterprises are the one who offers products consumed in everyday life and are from every broad domain of business, like food, groceries, medicine, education, internet services etc. They are Patanjali Ayurveda, Domino's Pizza India, Biotique Ayurveda, Bharti Airtel Limited, Spencer's Retail, Amity University, The Art of Living Foundation, Bajaj Allianz General Insurance, Lenskart India, and Tata Tele Business Services. At least one sponsored advertisement post from each company has been taken for this study. As mentioned earlier, the sponsored advertisement posts in some cases comprise a picture and sometimes a written message along with an image. Therefore, in the case of the former, we attempt to discuss the content of the picture, and in the latter's case; we will attempt a study of the written message and picture's content.

\section{Findings}

In the present day scenario, Facebook is not merely a platform for uploading photographs, writing posts and sharing daily updates, as suggested by Papasolomou \& Melanthiou (2012) instead, it has widened its scope. In modern times, it has "proved itself to be a low-cost information exchange platform available for one and all, be they consumers, businesses, organisations, governments, or any other entity, to learn, educate, share, build, market, advertise, and improve on the central idea being circulated" (Dwivedi et al., 2015, p. 290). "Now that 600 million potential customers are on Facebook, retailers are flocking to the site 
and aggressively experimenting with new communication strategies" (Saravanakumar \& Sugantha Lakshmi, 2012, p. 4447). Designed and structured in consideration with the current scenario, these advertisements are more likely to entice consumers who in this difficult time are in their home and separated from the outer world of the market.

Patanjali Ayurveda Limited is an Indian consumer goods company dealing with grocery items in general and ayurvedic medicine in particular. Spiritual Guru Swami Ramdevji and his associate Acharya Balkrishna own the company. Patanjali has set herself up as a famous brand in India as well as internationally. It has a huge fan following as it has targeted masses through Yoga and Pranayama, which Swami Ji himself teaches (Kumar et al., 2014). Patanjali's official Facebook page has 792,539 followers as of 26 April 2020. As the company sells "essential products" which are allowed during the lockdown period in India, it advertises them on Facebook through sponsored advertisements. Fig. 1 has the tagline "Make Good Use of Home Quarantine" followed by six oval pictures, which say, practice yoga, meditation, improve your health, pamper your skin, boost your immunity and spend time with your family.

Nevertheless, all suggestions are crucial during this time when COVID-19 traps the whole world. However, if we see the fifth oval picture, it is a product "Tulsi Ghanvati" made by Patanjali, which is used to relieve cold, fever, dengue, chicken guinea, and cough. In the same manner, fig. 2 has a tagline "Protect yourself and others from CORONAVIRUS". It has four oval pictures inside, of which two advertise the Patanjali product; "hand wash" and "Tulsi Ghanvati". There are other sponsored posts which have the tagline as "Give yourself a healthy treat during Self-Quarantine", and the company advertises food products. 


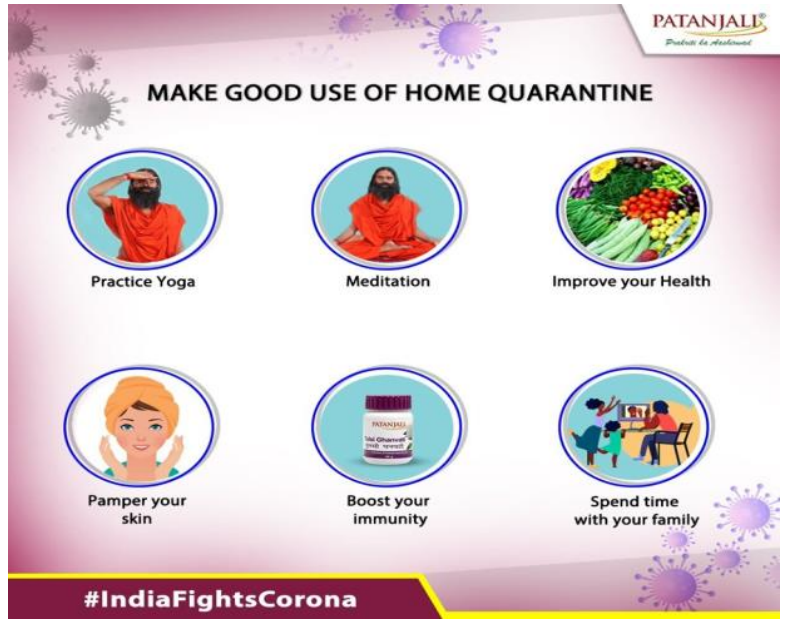

Fig. 1.

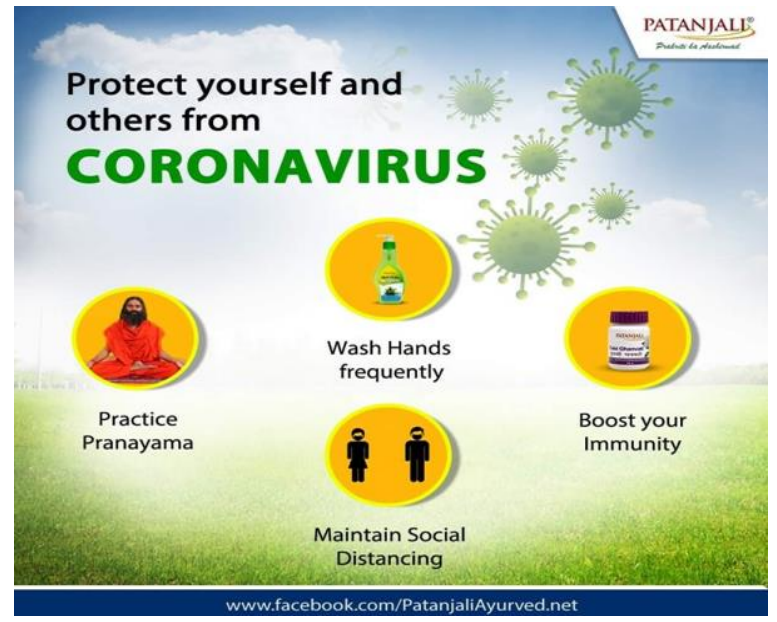

Fig. 2.

Domino's Pizza India is one of the famous pizza brands in India. It attracts a large number of Indian consumer chiefly youngsters and office going bachelors. As of 20 April 2020, the Domino's Pizza India Facebook page has more than seven lakh followers. Various social media posts have shown that people, especially the kids and the youngsters, are craving for Pizza during the lockdown. The company has continued its home deliveries restricted to some cities. In between for a short time, the company had also offered delivery of a few essential food items to households in megacities. Fig. 3 shows a post by the company which is cheering up its consumers. It says "Work from home extended? Don't worry as you still get to order your favourite Domino's Pizzas while you stay safe indoors and attend all your video conferences". As COVID 19 is a contagious virus, the company has invented a new marketing strategy by offering products to its afraid consumers through "zero contact delivery". In fig. 4, which is a section of Frequently Asked Questions (FAQs), the company tends to relate the "zero contact delivery" with extra charges and then making it free for its customers. 
Domino's Pizza India

April 14 at 9:39 PM

\#WorkFromHome extended? Don't worry as you still get to order your favourite \#DominosPizzas while you stay safe indoors and attend all your video conferences.

Our \#DominosFoodSoldiers are happy to serve you with hot \& fresh treats which are delivered safely without coming in direct contact with you, through \#ZeroContactDelivery.

\#Dominos \#DominosPizza \#BYOP \#BringYourOwnPizza \#DominosFoodSoldiers \#SafeCravings \#Lockdown2 \#DominosEssentials \#StayHome \#StaySafe \#SocialDistancing \#ZeroContactDelivery \#NoContactDelivery \#Dominos \#DominosPizza \#DominosPizzalndia \#Quarantine \#QuarantineLife \#QuarantineAndChill \#Friends \#Family \#Fun \#DominosCares \#SafeCravingsAgain

\section{Fig. 3.}
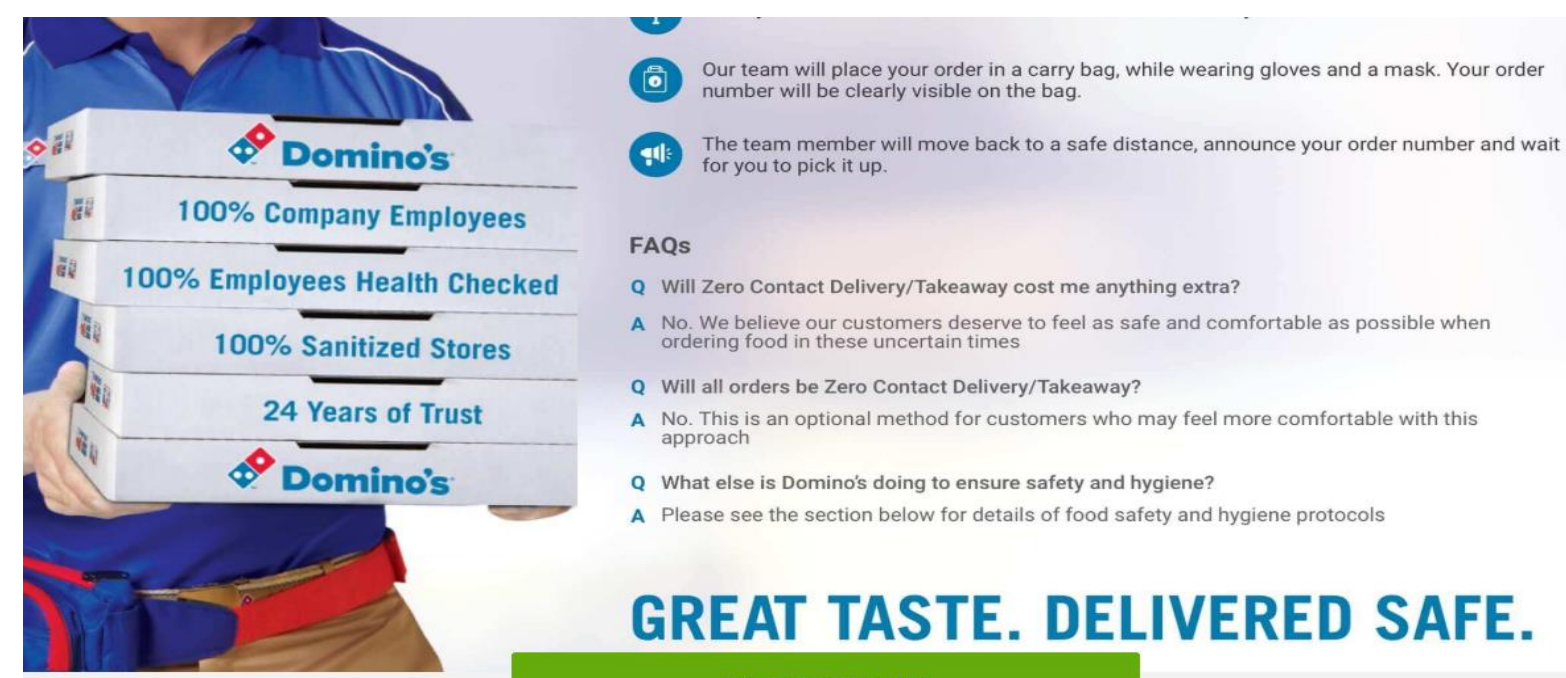
Our team will place your order in a carry bag, while wearing gloves and a mask. Your order
number will be clearly visible on the bag.

471: The team member will move back to a safe distance, announce your order number and wait
for you to pick it up. FAQs

Q Will Zero Contact Delivery/Takeaway cost me anything extra?

A No. We believe our customers deserve to feel as safe and comfortable as possible when ordering food in these uncertain times

Q Will all orders be Zero Contact Delivery/Takeaway? A No. This is an optional method for customers who may feel more comfortable with this
approach

Q What else is Domino's doing to ensure safety and hygiene?

A Please see the section below for details of food safety and hygiene protocols

\section{Fig. 4.}

Bharti Airtel Limited is a leading telecom company of India. With the imposition of lockdown, people staying at home have started using mobile and internet services excessively. People are now working from home using the internet, e.g. College teachers are engaging online classes, school teachers are sending class notes on emails and WhatsApp. Thus, internet data consumption has increased manifold. Besides, as people are at home, they are likely to watch Television and access entertainment services through laptops and mobile 
phones. The company's Facebook page has more than one million followers. The sponsored advertisement posts of Airtel, mention catchy statements like "Working from Home? Get unlimited data", "No more getting bored at home: Buy DTH online and get $50 \%$ off", "Enable your business with Airtel work-from-home solutions", etc. One such advertisement can be seen in fig. 5. Once a person clicks the ad, it will take him/her to the enticing Airtel website, where there are offers and solutions for his/her needs. The company has started providing remote connectivity solutions through corporate broadband, corporate mi-fi, etc.

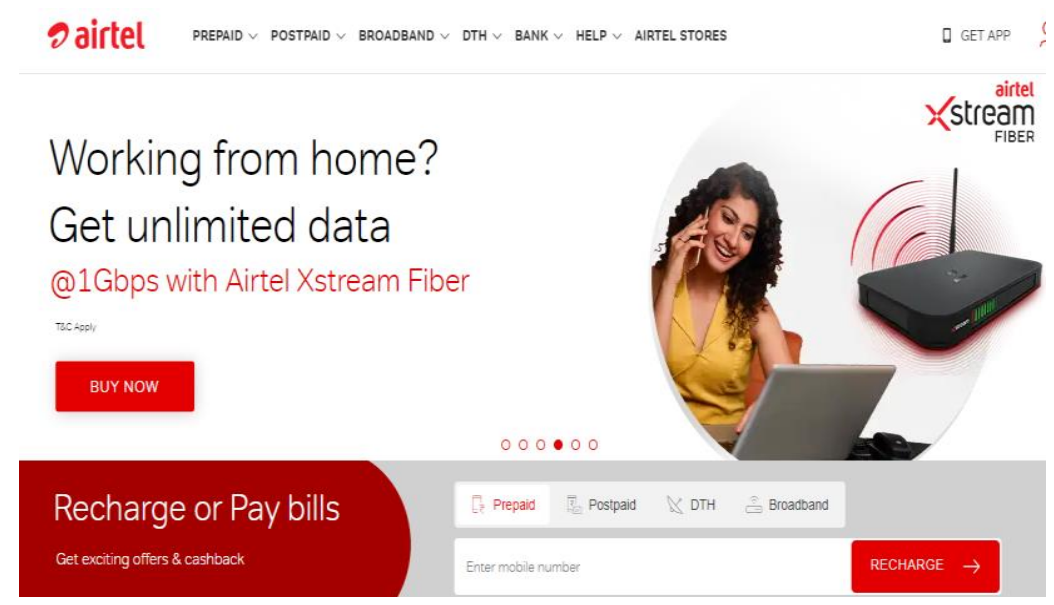

Fig. 5.

Spencer's is a leading retail company based in India. Its website states that it is a "multi-format retailer providing a wide range of quality products across categories such as food, personal care, fashion, home essentials, electrical \& electronics to its consumers" (Spencer's, n. d. ). As the company deals in "essential goods", it is relieved from the lockdown restrictions. The Facebook page of the company has more than 3.5 lakh followers. The company has started writing enticing posts stating, "Even when you're quarantined, that's no excuse to celebrate your special days". The special day can be a wedding anniversary or birthday of your loved ones or any such occasions. Fig. 6 is a post about 
wedding anniversary, which states "Anniversary ki sari taiyari, delivery humari" (Get ready to celebrate your anniversary; we (Spencer's) will deliver the required).

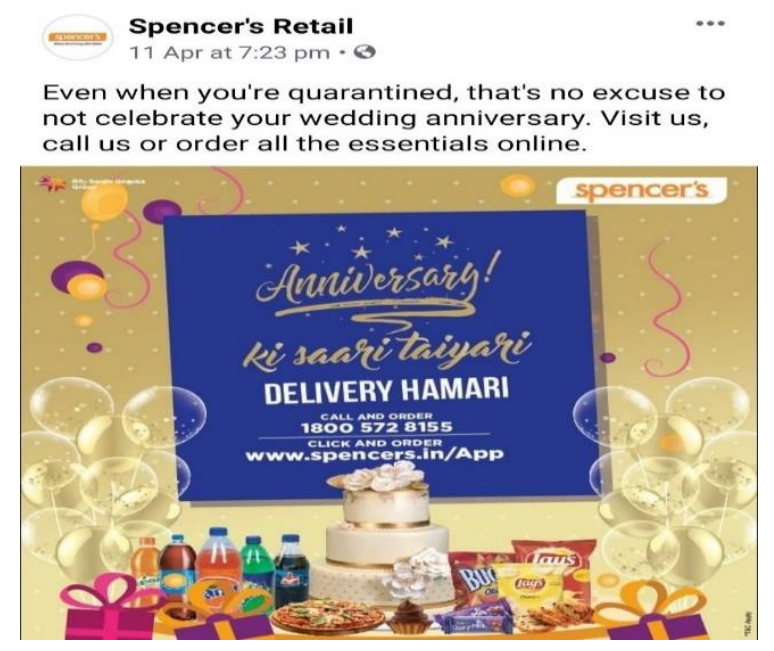

Fig. 6.

\author{
Spencer's Retail \\ 10 Apr a t11:30 am $\cdot \theta$ \\ Don't let this quarantine come in the way of your \\ happy pudding making sessions. \\ Put on your aprons and chef hats and learn \\ something new this Quarantine. \\ Visit us, call us or order all the ingredients online.
}

In another post, which advertises sandwich, Spencer's refers to its work staffs as Quaranteam (meaning those who work during quarantine). The lockdown has brought an opportunity for people to follow their hobbies, to show their hidden talents, or to try at least one new thing. One such thing is cooking, and now when people are locked at home, they are trying cooking. A plethora of food recipes and cooking tips are being posted and shared on Facebook. Spencer uses the opportunity to advertise and sell its products. Fig. 7 is a tempting advertising post for the lovers of cooking.

Biotique is a brand of Bio Veda Action Research Company based in India. It deals in herbal cosmetic products. Biotique has emerged as a famous cosmetic brand in the recent decade when people have started preferring organic products to chemical-based products. The company's website states that its "products are made of $100 \%$ organically-pure, preservativefree ingredients and renewable resources - cultivated, gathered, blended and manufactured in the foothills of the Himalayas" (Biotique, n. d.). The company's Facebook page has more than 3.5 lakh followers. One of the advertisement picture posts of Biotique on Facebook has a 
tagline, "Which skin \& hair care essential is a must when you are working from home?" Fig.

8 is another post that mentions the lockdown to advertise its product.

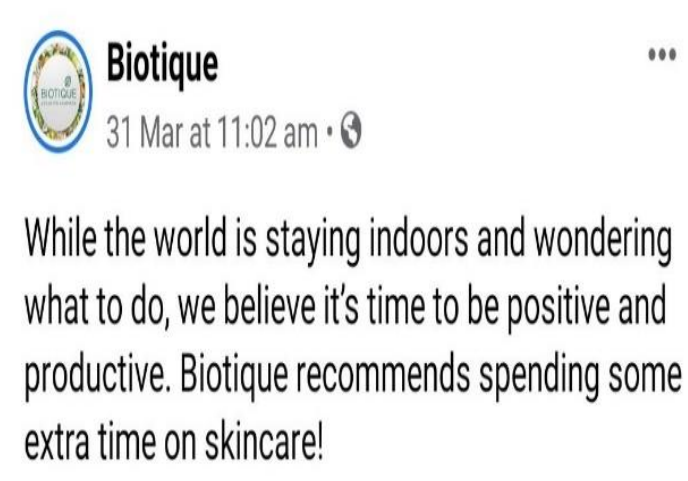

Let's share some positive ideas about spending some quality durina this lockdown.

\author{
Biotique \\ 9 Apr at $3: 20 \mathrm{pm} \cdot \Theta$ \\ Looking at the current Pandemic it's high time we \\ leave ourselves in the pure hands of nature to \\ protect us. Quite Literally. And that's why, \\ \#Biotique brings to you its natural range of hand \\ sanitizes to offer you protection and care. \\ Because for us, what matters most is you. \\ Buy now: https://bit.ly/2XljODp
}

\section{\#HandSanitizers \#StaySafeWithBiotique \#KilltheCorona \#NewLaunch \#advancedayurveda}

Fig. 8.

Fig. 9.

Fig. 9 is a post by the company, which advertises its newly launched "hand sanitiser", arousing its consumers to leave themselves in the hands of nature. The picture attached with this post mentions hashtag "Kill the Corona" with the power of Ayurveda.

Along with the "essential items" providing companies, there are other enterprises of "non-essential items" or that of other sectors that have used the period of lockdown to attract customers through their sponsored advertisement posts. These enterprises are giving offers on their products to enhance their selling rate, which has come down drastically during the lockdown period. Fig. 10 is a sponsored post by Amity University, a private university chain in India. The University is advertising its MBA degree programme through Facebook posts. The message embedded in the post states that it is a "limited period initiate by Amity so that India never stops learning" during this lockdown period. The course fee is just INR 30,000 , which, the university terms as a "lockdown price". In addition, as it is an online MBA programme, one can access it working from home, through the internet. 


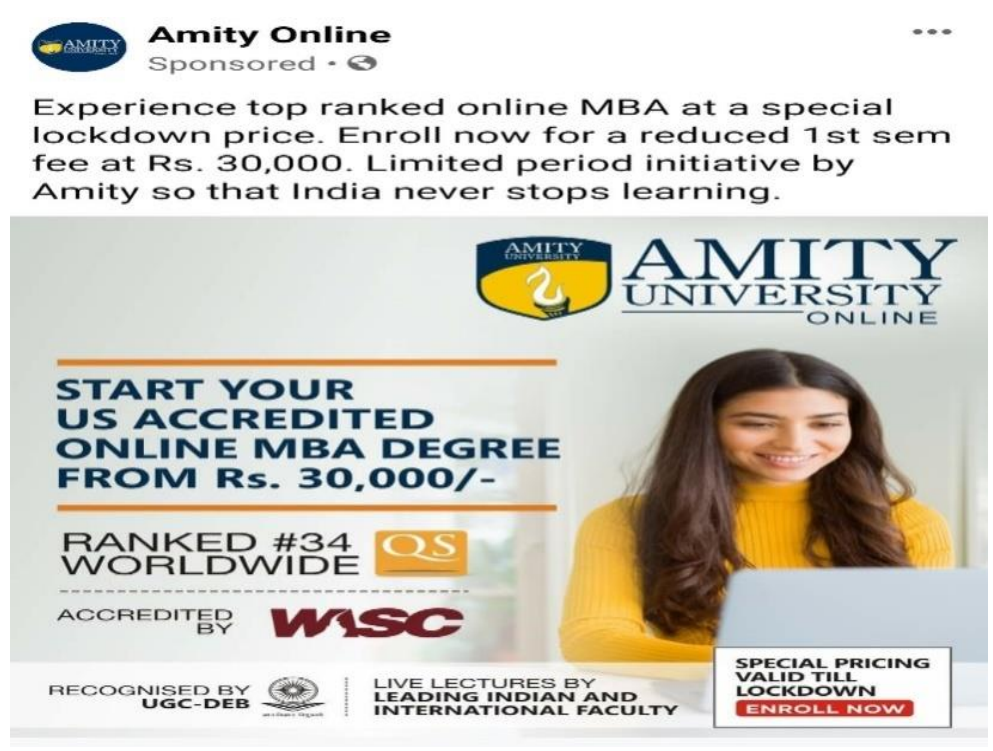

Fig. 10.

One crucial precautionary measure to avoid COVID 19, as suggested by the doctors and health experts is to avoid touching our nose, eyes and face. Touching our face so much may increase the risk of infection. According to the World Health Organization (2020), "Hands touch many surfaces and can pick up viruses. Once contaminated, hands can transfer the virus to your eyes, nose or mouth. From there, the virus can enter your body and can make you sick. Many people do this activity more often, inadvertently", therefore we must avoid touching eyes, nose and mouth. Fig. 11 is an advertisement post by Lenskart, an Indian eyewear business enterprise. The content of the post showcases how the company is manipulating one of the essential health advisories of WHO about avoiding face touch. The post presents "specs" as comparable to "masks". It also claims that like masks, the specs can be effective in keeping one away from touching his/her eyes. The picture in the post states that "Be safe with your specs on", and the pair in the picture can be seen wearing masks along with specs. The hashtag of the post also mentions "Stay safe wear safe", thus reiterating the importance of its product which can keep its consumer safe. 


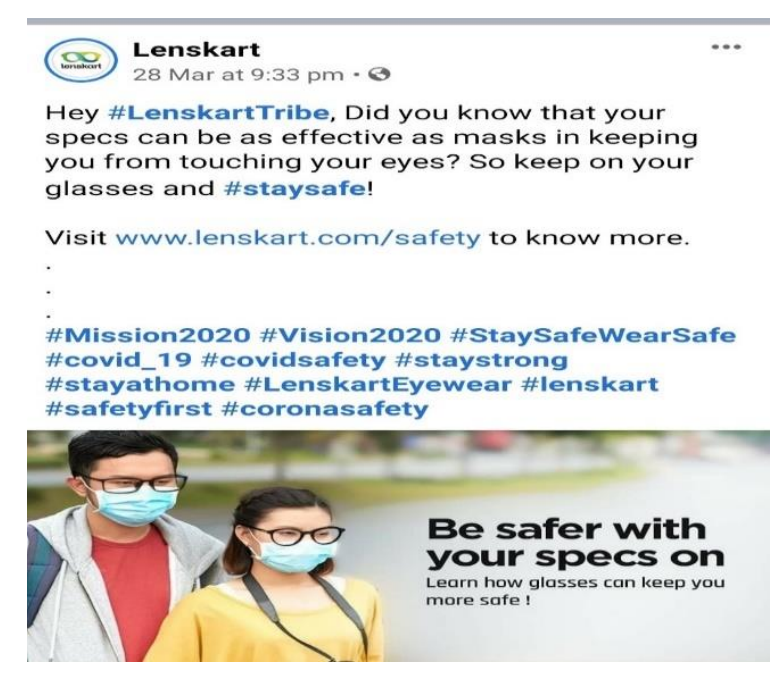

Fig. 11.

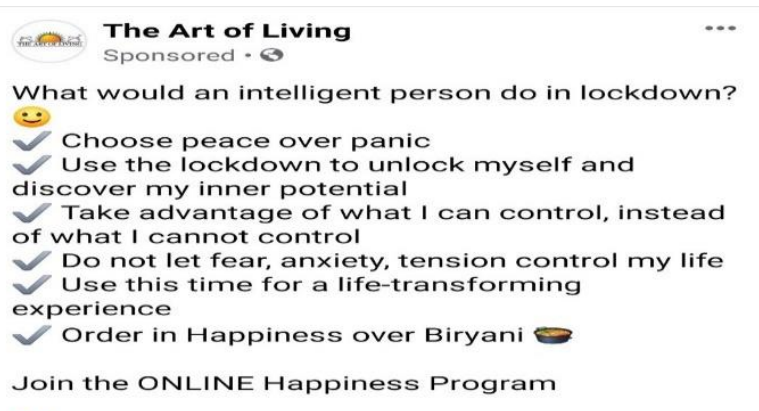

II $50 \%$ OFF (for a limited time only)

Designed by the pioneers of breathing and meditation techniques who have brought years of authentic programs in over 156 countries

Now is the time - Just log on! $\Rightarrow$ artofliving.org/ onlinehp

\#HappinessHomeDelivered

The lockdown has affected the psychological health of humans in both a positive and negative way. It has provided humans with many opportunities to engage in various auxiliary activities that can be done sitting at home. On the other hand, continuously staying home for an extended period, with the same setting and repetitious activity has affected the human mind negatively. In a recent review article on the psychological impact of quarantine on people, Brooks et al. (2020) have found that "the psychological impact of quarantine is wideranging, substantial, and can be long-lasting" (p. 919). Gelder et al. (2020) have identified that "Quarantine, isolation and associated social, emotional and economic stressors increase the risk of intimate partner violence (IPV)" (p. 2). However, the consumer market has a solution for every human problem. Fig. 12 is a sponsored post by The Art of Living, an India based NGO working for the spiritual, social well-being of humans. Sri Sri Ravi Shankar Ji, a renowned spiritual leader, is the founder of the NGO. The official Facebook page of this organisation has more than two lakh followers. The organisation runs many paid Happiness Programs (through yoga and meditation). The post has a very catchy tagline "What would an intelligent person do in lockdown?" followed by six must-do options. The sixth option entices 
its consumers to spend money on Happiness program instead of spending money on food (Biryani). The organisation also offers $50 \%$ off for a limited period.

\section{Discussion}

This study has discussed the contents of select sponsored advertisement posts of a few enterprises floated on Facebook. The study finds that these posts have used words like Quarantine/Lockdown/Work from Home, which are popular and topical these days, to advertise their products. It is very appropriate here to quote Baudrillard (1970), who says,

Advertising is prophetic language, in so far as it promotes not learning or understanding but hope. What it says presupposes no anterior truth (that of the object's use value), but an ulterior confirmation by the reality of the prophetic sign it sends out. This is how it achieves its end. It turns the object into a pseudo-event, which will become the real event of daily life through the consumer's endorsing its discourse. (p. 127)

This study has shown how the lockdown period has been used to create atmospherics, for selling "essential items" as well as "non-essential items" by various E-commerce companies and other enterprises. Demands of hand-wash liquids and sanitisers have suddenly increased exponentially, and two big ayurvedic brands Patanjali and Biotique are subtly advertising their newly launched sanitiser and hand-wash liquids at the behest of using organic and hundred percent natural products. Domino's is luring its customer's through a new marketing strategy by creating "zero contact delivery" to sell its products. Airtel has opened up a set of solutions to your everyday internet need. It has created products keeping in view the current lockdown demand. It has plans for TV lovers as well as "work from home solutions" for both individual and corporate. Spencer's are enticing their customers through a range of product deliveries for special occasions. They tend to care for your special days and use this as a 
marketing strategy. Enterprises of "non-essential items" are no less behind in creating luring advertisements for their consumers. The organisation like Amity University and The Art of living have created a special offer calling it the "lockdown price", to sell their products/services. This "lockdown price" is, basically, half of the actual price of their product/services or say their products/services are at $50 \%$ off. Lenskart has experimented with a new marketing strategy to sell its product by stating that masks are comparable to specs. They have cleverly wangled the fact that one need not touch his/her face into a tempting marketing strategy.

According to the World Trade Center (2020), "Despite persistent challenges, in light of the pandemic, online purchases, and e-commerce have become de facto fall -back solutions". There is no literature yet available, that can show how much the companies profited during the lockdown period. However, there is literature like Das \& Das (2020) that estimates "state wise and economic-activity wise economic loss" (p. 21) during the first phase of the COVID19 lockdown in India. It is difficult to ascertain the profit of the above-mentioned companies during the lockdown period as COVID-19 has badly affected the economy of the enterprises as well as the country. Besides, many other factors need to be taken into consideration before such an estimation is visualised. This study doesn't attempt to go into the profit/loss intricacies; instead, it has argued how the enterprises, with their capitalist zeal, tried their best to entice the customers through the sponsored advertisements. Facebook acted as the best platform for advertisement in these hard times.

\section{Conclusion}

The contents of the aforementioned sponsored advertisements establish the fact that the lockdown has created an atmospheric for business. The companies have targeted to tempt their consumers through Facebook sponsored advertisement post. Keeping into consideration, 
the large number of followers of these companies/organisations on Facebook, it can be said that their sponsored advertisement posts likely hit a considerable number of consumers. It might have resulted in sound business and ample sale of products/services, which apparently seems difficult during these hard times. The study concludes that the business organisations have commodified the lockdown period in India along with words and phrases like "quarantine" and "work from home", to sell their products and services. Facebook helped these enterprises immensely to reach a broader consumer during the lockdown period. This study also establishes the fact that however, the situation is, good or bad, whatever times the people are going through, either good or bad, the capitalistic approach of the business organisation tends them to invent new marketing strategies, topical to the time, for selling their products and services. As such, it may be said that negative is not always negative as it may have a positive outcome for some if used diplomatically.

\section{References}

Baudrillard, J. (1970). The Consumer Society: Myths and Structures. London: Sage

Biotique. (n. d.). About us. Retrieved 20 April 2020 from, https://www.biotique.com/about-us

Brooks, S.K., Webster, R.K., Smith, L.E., Woodland, L., Wessely S., Greenberg N., Gideon, J.R. (2020). The psychological impact of quarantine and how to reduce it: rapid review of the evidence. Lancet, 395, 912-920. https://doi.org/10.1016/S01406736(20)304608

Clement, J. (2020, February 28). Facebook's advertising revenue worldwide from 2009 to 2019. Statista. Retrieved 2 June 2020 from, https://www.statista.com/statistics/271258/facebooks advertising-revenue-worldwide/

Das, T., \& Das, D. (2020). COVID-19 and Economic Loss of First Phase of (21- Day) Lockdown in India. Space and Culture India, 8 (1), 21-26. 
Deloitte. (n. d.) Digital Media: Rise of On-Demand Content. Retrieved 15 June 2020 from, https://www2.deloitte.com/content/dam/Deloitte/in/Documents/technology-media telecommunications/in-tmt-rise-of-on-demand-content.pdf

Dwivedi, Y., Kapoor, K., \& Chen, H. (2015). Social media marketing and advertising. The Marketing Review, 15(3), 289-309.https://doi.org/10.1362/146934715X14441363377999

Gelder, N. van., Peterman. A., Potts, A., O’Donnell, M., Thompson, K., Shah, N., Oertelt Prigione, S. (2020). COVID-19: Reducing the risk of infection might increase the risk of intimate partner violence, EClinicalMedicine. https://doi.org/10.1016/j.eclinm.2020.100348

Herat, M. (2020). I feel like death on legs: COVID-19 isolation and mental health. Social Sciences \& Humanities Open, 2 (1), 1-8.

Hutchinson, A. (2020, April 29). Facebook is the Leading Social Platform for News During COVID-19. Social Media Today. Retrieved 12 June 2020 from, https://www.marketwatch.com/story/facebook-in-the-age-of-covid-19-users-are online-but-will-advertisers-pay-to-get-to-them-2020-04-06

IBEF. (2019). Indian Retail Industry Report. India Brand Equity Foundation. Retrieved 19 April 2020 from, https://www.ibef.org/industry/retail-india.aspx

Kadam, A. B., \& Atre, S. R. (2020). Negative impact of social media panic during the COVID-19 outbreak in India. Journal of Travel Medicine, 1-2, doi: $10.1093 / \mathrm{jtm} / \mathrm{taaa} 057$

Kumar, V., Jain, A., Rahman, Z., \& Jain, A. (2014). Marketing through spirituality: A case of Patanjali Yogpeeth. Procedia-Social and Behavioral Sciences, 133, 481-490. https://doi:10.1016/j.sbspro.2014.04.215 
Mandavia, M. (2019, September 26). India has second-highest number of Internet users after China: Report. The Economic Times. Retrieved 20 April 2020 from, https://economictimes.indiatimes.com/tech/internet/india-has-second-highestnumber of internet-users-after-china-report/articleshow/71311705.cms?from=mdr

Newman, N. (2020). Reuters Institute Digital News Report 2020. Retrieved 19 June 2020, from, https://www2.deloitte.com/content/dam/Deloitte/in/Documents/technology media telecommunications/in-tmt-rise-of-on-demand-content.pdf

Osadchuk, M. A., Trushin, M. V., \& Osadchuk, A. M. (2020). COVID-19 \& Quarantine Measures: A Comparison between India and Russia. Space and Culture, India, 8 (1), 27-38.

Papasolomou, I., \& Melanthiou, Y. (2012). Social media: Marketing public relations' new best friend. Journal of Promotion Management, 18 (3), 319-328. https://doi.org/10.1080/10496491.2012.696458

Prashar, S., Sai Vijay, T., \& Parsad, C. (2017). Effects of Online Shopping Values and Website Cues on Purchase Behaviour: A Study Using S-O-R Framework. Vikalpa, 42(1), 1-18. https://doi.org/10.1177/0256090916686681

Saravanakumar, M., \& SuganthaLakshmi, T. (2012). Social Media Marketing. Life Science Journal, 9(4), 4444-4451.

Schilirò, D. (2020). Towards the Digital Globalization and the COVID-19 challenge. International Journal of Business Management and Economic Research, 11(2), 17101716. 
Schwarzl, S., \& Grabowska, M. (2015). Online marketing strategies: the future is here. $\begin{array}{llllll}\text { Journal of } & \text { International } & \text { Studies, } & 8 & \text { (2), }\end{array}$ https://doi.org/10.14254/20718330.2015/82/16

Sharma, G. D., \& Mahendru, M. (2020). Lives or livelihood: Insights from locked-down India due to COVID-19. Social Sciences \& Humanities Open, 2 (1), 1-3.

Spencer's (n. d.). About us. Retrieved 20 April 2020 from, https://www.spencers.in/about_us/

Swartz, J. (2020). Facebook is experiencing record usage, but will advertisers spend during spread of corona virus? Market Watch. Retrieved 5 June 2020 from, https://www.marketwatch.com/story/facebook-in-the-age-of-covid-19-users-are online-but-will-advertisers-pay-to-get-to-them-2020-04-06.

World Health Organization. (2020). Basic protective measures against the new coronavirus, WHO. Retrieved 24 April 2020 from, https://www.who.int/emergencies/diseases/novelcoronavirus-2019/advice-forpublic.

World Trade Organization. (2020a). E-commerce, Trade and the COVID-19 Pandemic. $\begin{array}{lllll}\text { Retrieved } & 24 & \text { June } & 2020 & \text { from, }\end{array}$ https://www.wto.org/english/tratop e/covid19 e/ecommerce report e.pdf 